\section{Dr. Fernández-Fernández and Dr. Sesma reply}

\section{To the Editor:}

We thank Dr. Park and colleagues ${ }^{1}$ for their interest in our letter ${ }^{2}$. They note another mechanism by which $\mathrm{N}$-acetylcysteine might be useful as adjuvant therapy for patients with antineutrophil cytoplasmic antibody (ANCA)-associated vasculitis. The studies that they cite ${ }^{3,4,5}$, along with those that we mentioned ${ }^{6,7}$, could be the basis to evaluate the hypothetical potential of high-dose acetylcysteine as an anti-vasculitic drug in randomized, placebo-controlled trials in humans. Meanwhile, the IFIGENIA trial (Idiopathic Pulmonary Fibrosis International Group Exploring N-Acetylcysteine I Annual study) ${ }^{8}$ revealed an interesting finding for patients treated with azathioprine that may have been overlooked. The dose of azathioprine in this trial was similar to doses used in patients with ANCA-associated vasculitis, and the bone marrow toxicity was significantly less frequent with acetylcysteine than with placebo. We believe that this lower hematologic toxicity justifies the study of high-dose acetylcysteine in patients with ANCA-associated vasculitis treated with azathioprine, regardless of a hypothetical anti-vasculitic action.

FRANCISCO JOSÉ FERNÁNDEZ-FERNÁNDEZ, MD; PASCUAL SESMA, PhD, Department of Internal Medicine, Hospital Arquitecto Marcide, Ferrol 15405, Spain. Address correspondence to

Dr. Fernández-Fernández; E-mail: fjf-fernandez@terra.es

\section{REFERENCES}

1. Park SJ, Pai KS, Kim JH, Shin JI. Beneficial effect of $\mathrm{N}$-acetylcysteine on antineutrophil cytoplasmic antibody-associated vasculitis [letter]. J Rheumatol 2012;39:186.
2. Fernández-Fernández FJ, Sesma P. Acetylcysteine as adjuvant therapy for vasculitis associated with antineutrophil cytoplasmic antibody. J Rheumatol 2011;38:785.

3. Spapen H, Zhang H, Demanet C, Vleminckx W, Vincent JL, Huyghens L. Does N-acetyl-L-cysteine influence cytokine response during early human septic shock? Chest 1998;113:1616-24.

4. Hsieh SC, Yu HS, Cheng SH, Li KJ, Lu MC, Wu CH, et al. Anti-myeloperoxidase antibodies enhance phagocytosis, IL-8 production, and glucose uptake of polymorphonuclear neutrophils rather than anti-proteinase 3 antibodies leading to activation-induced cell death of the neutrophils. Clin Rheumatol 2007;26:216-24.

5. Willems J, Joniau M, Cinque S, van Damme J. Human granulocyte chemotactic peptide (IL-8) as a specific neutrophil degranulator: Comparison with other monokines. Immunology 1989;67:540-2.

6. Wu Z, Turner DR, Oliveira DB. Antioxidants inhibit mercuric chloride-induced early vasculitis. Int Immunol 2002;14:267-73.

7. Guilpain P, Servettaz A, Batteux F, Guillevin L, Mouthon L. Natural and disease associated anti-myeloperoxidase (MPO) autoantibodies. Autoimmun Rev 2008;7:421-5.

8. Demedts M, Behr J, Buhl R, Costabel U, Dekhuijzen R, Jansen $\mathrm{HM}$, et al for the IFIGENIA Study Group. High-dose acetylcysteine in idiopathic pulmonary fibrosis. N Engl J Med 2005;353:2229-42.

J Rheumatol 2012;39:1; doi:10.3899/jrheum.111105 